\title{
EFFECT OF SWARD HEIGHT ON THE PRODUCTIVITY OF GRASS/CLOVER AND NITROGEN FERTILIZED GRASS SWARDS CONTINUOUSLY GRAZED BY SHEEP
}

\author{
D. M. B. CHESTNUTT
}

Agricultural Research Institute of Northern Ireland, Hillsborough, Co. Down BT26 6DP

\section{INTRODUCTION}

$\mathbf{R}$ ecent studies (Hodgson, 1986; Penning, 1986) have emphasized the importance of sward surface height as a major influence on animal productivity and recommendations for the control in sheep grazing are now given in terms of sward height (Maxwell and Treacher, 1987). However, there is a need for a clearer definition of the relationships involved over the entire grazing season and on different sward types. Whilst clover is known to be a potentially important component of sheep pastures there is limited information on how the reaction to sward height differs in grass, compared with grass/clover, swards. Therefore, it was decided to compare the productivity of nitrogen $(\mathrm{N})$ fertilized grass and grass/clover swards, grazed by sheep throughout the season, to a range of sward heights.

\section{MATERIAL AND METHODS}

A perennial ryegrass (cv. Talbot), white clover (cv. Huia), sward sown in 1981 and which for 5 years had been used in a comparison of grass/clover and grass/ nitrogen systems with cattle, is being used in the present study which commenced in 1987 . Initially, clover was well distributed throughout the clover swards. Grass/ clover swards received a dressing in the spring of $50 \mathrm{~kg} \mathrm{~N}$ per ha and no $\mathrm{N}$ throughout the rest of the year. Grass/nitrogen swards received a total of $300 \mathrm{~kg} \mathrm{~N}$ per ha in six equal dressings, the first in mid March, the second 6 weeks later and with subsequent dressings at 4-weekly intervals. $\mathrm{N}$ was applied as a compound containing $\mathrm{N}, \mathrm{P}_{2} \mathrm{O}_{5}$ and $\mathrm{K}_{2} \mathrm{O}$ in the ratio $27: 6: 6$. In mid June $55 \mathrm{~kg} \mathrm{P}_{2} \mathrm{O}_{5}$ and $55 \mathrm{~kg} \mathrm{~K}_{2} \mathrm{O}$ per ha were applied to grass clover plots. Soil analysis at the start of the experiment indicated a $\mathrm{pH}$ of 5.9 and phosphorus and potassium status in categories 4 and 2 respectively.

An area of 6.7 hectares was divided into 32 paddocks so that there were four $0 \cdot 167$-ha grass/nitrogen paddocks and four $\mathbf{0} \cdot 25$-ha grass/clover paddocks in each of four replicates. Four grazing heights, $3,5,7$ and $9 \mathrm{~cm}$ were randomly allocated to the four paddocks. In 1987, the first ewes were turned out when a mean sward height of
$5.0 \mathrm{~cm}$ was reached on 17 April and the required range of sward heights was reached on 5 May. During the winter 1987/88 all swards were grazed to a uniform height. In 1988, ewes were turned out first on 25 March at a mean sward height of $4.5 \mathrm{~cm}$ and the required range was established by 19 April.

The 'experimental' stocking of each paddock consisted of two ewes suckling a total of three lambs. These remained on paddocks from turn-out to weaning. In addition to these, 'non-experimental' ewes suckling

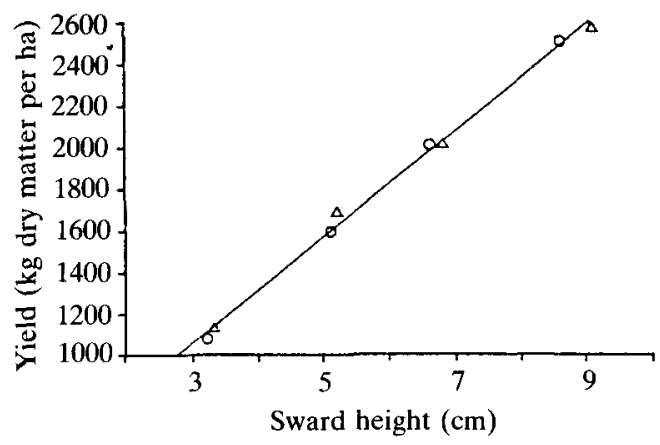

FIG. 1. Effect of sward height on pasture yield (April to July); $O$ grass/nitrogen; $\triangle$ grass/clover.

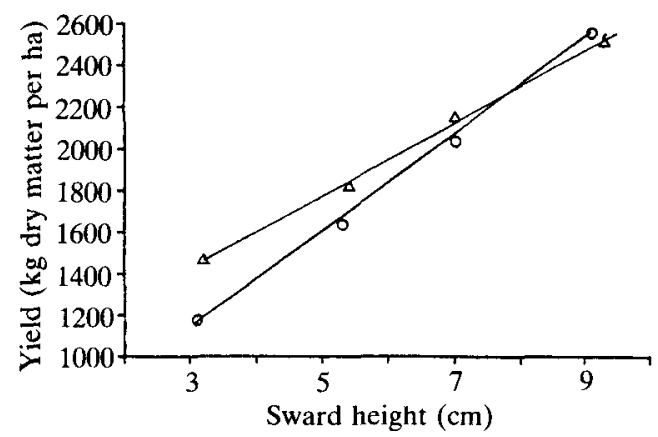

FIG. 2. Effect of sward height on pasture yield (August to October); $O$ grass $/$ nitrogen; $\triangle$ grass/clover. 
lambs were added or removed from paddocks as necessary to maintain the required sward height. Adjustments to stock numbers on each paddock were made on the basis of twice weekly measurements of pasture height using a sward stick. A minimum of 40 height measurements per paddock were taken. 'Experimental' ewes and their lambs were weighed weekly and gains quoted are based on regressions over the period.

After weaning sward heights were maintained by adjusting numbers of dry ewes. By mid July pastures maintained at 9,7 and $5 \mathrm{~cm}$ had developed seed heads to such an extent that topping was necessary. The yield of toppings was recorded and they were removed from paddocks. From 19 August to 6 October 1987 and from 2 August to 5 October 1988 three 'experimental' lambs (mean initial weight $32 \mathrm{~kg}$ ) were grazed on each paddock and heights were maintained at the same levels as before weaning by adding or removing dry ewes as necessary. Lamb weights were recorded on a weekly basis and rates of weight gain are based on regressions over the period.

The yield of standing pasture was measured by cutting six sample quadrats $\left(0 \cdot 1 \mathrm{~m}^{2}\right)$ from each paddock at 2 -week intervals. At monthly intervals six random samples of herbage from each paddock were bulked and separated to determine clover content of pastures. Rates of tissue turn-over were also measured but these data are not included in this publication.

\section{RESULTS}

The relationship between sward height and standing pasture yield is shown in Figure 1 for the period before weaning and in Figure 2 for the period after weaning. Sward heights were maintained close to the set values with little difference in the heights of grass/nitrogen and grass/clover swards. Mean clover content expressed as a proportion of the harvested herbage based on monthly measurements are given in Table 1. Clover levels did not differ significantly in 1987 but by the end of the 1988 season clover content in the $9 \mathrm{~cm}$ grass/clover swards was significantly lower than at other heights.

The effect of sward height on the performance of ewes and lambs during the period up to weaning is shown in

TABLE 1

Mean proportion of clover in standing pasture

$\begin{array}{ccc}\begin{array}{c}\text { Sward height } \\ (\mathrm{cm})\end{array} & 1987 & 1988 \\ 3 & 0.050 & 0.023 \\ 5 & 0.043 & 0.018 \\ 7 & 0.056 & 0.034 \\ 9 & 0.048 & 0.010 \\ \text { s.e. } & 0.0092 & 0.0057\end{array}$

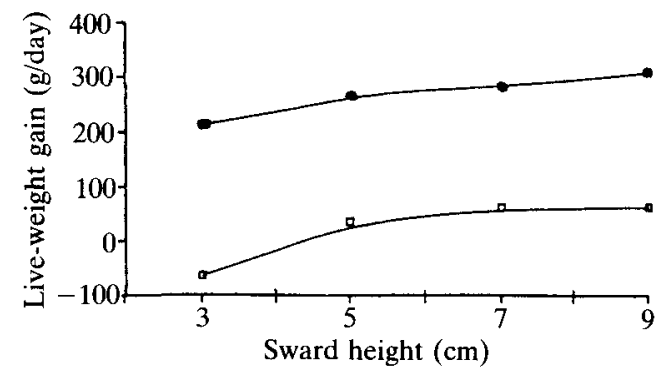

FIG. 3. Effect of sward height (mean of sward types) on weight change in ewes ( $\square$ ) and lambs $(\boldsymbol{O})$ before weaning.

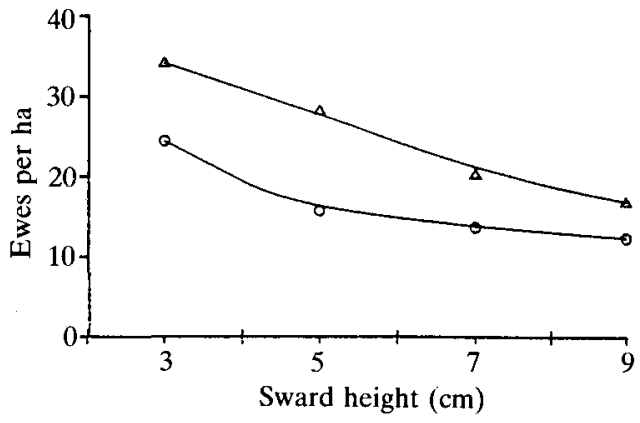

FIG. 4. Effect of sward height and type on stocking rate before weaning; $\triangle$ grass/ nitrogen; $\bigcirc$ grass/clover.

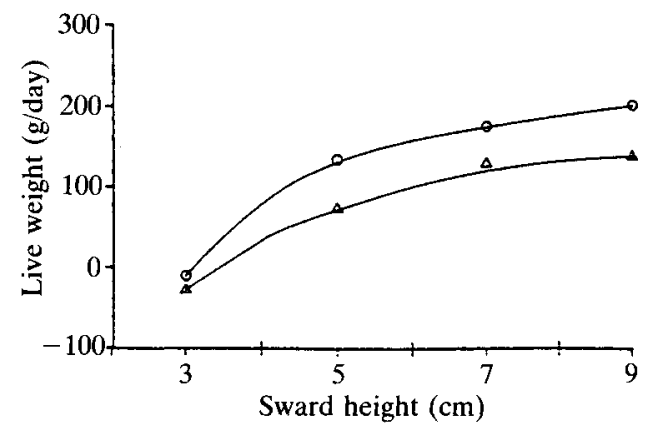

FIG. 5. Effect of sward height and type on rate of gain of lambs in autumn; $\triangle$ grass/ nitrogen; $\bigcirc$ grass/clover.

Figure 3. While there was no significant difference between sward types in 1987 , lambs on the grass/clover swards gained significantly more than those on grass/ nitrogen swards in 1988 (234 v. $272 \mathrm{~g} /$ day on grass/ nitrogen and grass/clover swards respectively; s.e. 7.05). Ewe performance was not affected by sward type and results have been combined over sward types in Figure 3. The major effect on lamb performance occurred as sward height was increased from 3 to $5 \mathrm{~cm}$. Whilst the 
differences resulting from further increases in sward height were small, there was evidence of increasing gain throughout the range of sward heights examined. There was a substantial reduction in the weight of ewes on $3 \mathrm{~cm}$ swards but little difference between the other heights.

The effect of treatments on stock-carrying capacity of swards is shown in Figure 4. There was a large increase in the number of ewes carried when the sward height was reduced to $3 \mathrm{~cm}$. Grass/clover swards on average carried proportionately 0.66 of the stock carried on grass/ nitrogen swards. The effect of changes of sward height on stock-carrying capacity was considerably greater between 3 and $5 \mathrm{~cm}$ than between 7 and $9 \mathrm{~cm}$.

The effect of treatments on the rate of gain of weaned lambs during the autumn period is shown in Figure 5. Lamb performance at this stage was affected by sward height over the entire range of heights examined but the increase in gain between the 3 and $5 \mathrm{~cm}$ heights ( $122 \mathrm{~g} /$ day) was considerably greater than the increase between 7 and $9 \mathrm{~cm}$ heights ( $18 \mathrm{~g} /$ day). Performance on grass/clover swards (mean gain $125 \mathrm{~g} /$ day) was greater at all sward heights than performance on grass/nitrogen swards (mean gain $78 \mathrm{~g} /$ day).

The effect of treatments on sward-carrying capacity in the autumn is shown in Figure 6. Again the effect of sward height was greatest at the lower heights, the weight of stock carried at $5 \mathrm{~cm}$ being proportionately 0.64 of that carried at $3 \mathrm{~cm}$ while the weight carried at $9 \mathrm{~cm}$ was proportionately 0.93 of that carried at $7 \mathrm{~cm}$. There was a wide difference between carrying capacities of the two sward types with grass/clover swards carrying proportionately 0.51 of the live weight carried on grass/nitrogen swards.

\section{DISCUSSION}

The relationship between sward height and standing pasture yield appeared to be linear and there was no consistent evidence of a difference between sward types

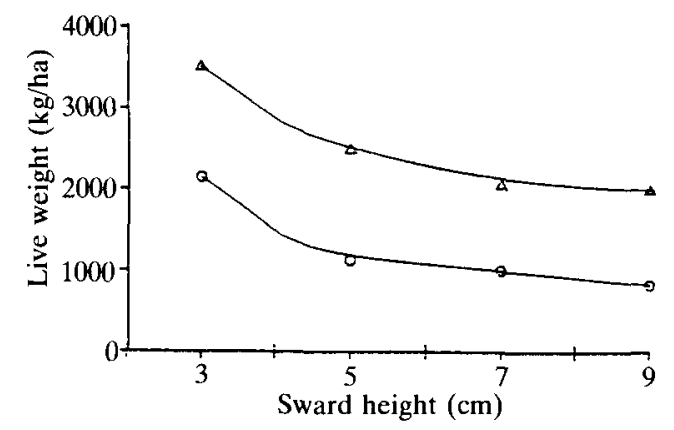

FIG. 6. Effect of sward height and type on sward-carrying capacity in autumn; $\triangle$ grass/nitrogen; $\bigcirc$ grass/clover. in spring. In autumn, however, the increase in standing pasture yield per unit increase in sward height was greater in grass/clover than on grass/nitrogen swards, suggesting a somewhat denser grass/clover sward. On average throughout both years standing pasture yield increased by $227 \mathrm{~kg}$ dry matter per ha per $\mathrm{cm}$ increase in pasture height. At the start of the experiment there appeared to be a good clover content on the grass/clover areas as measured by growing point numbers and a good distribution of clover over the grazing area. However, clover yields were low throughout the experiments, particularly in the 2 nd year, reaching a maximum of proportionately only 0.054 of herbage harvested in June 1987. While clover contents have commonly been lower in continuously grazed swards than under rotational grazing (Newton, Wilde and Betts, 1984), clover proportions in the standing herbage of the same order as those in the present experiment have been recorded by Marsh and Laidlaw (1978) and by Newton et al. (1984) under continuous grazing. There was little evidence of an increase in clover content in swards in the autumn in 1987 when the highest content was recorded in June. In 1988 , clover increased from a very low proportion of dry matter yield (0.011) in spring to 0.042 in August.

Live-weight gain in lambs has been shown to be relatively insensitive to the proportion of clover consumed (Gibb and Treacher, 1984) and improved performance on grass/clover swards appeared to result from increased herbage intake. In terms of the measured standing pasture yield the proportional contribution of clover in the autumn period of the present experiment was small at around 0.03 of the dry matter, yet this resulted in a mean increase of $47 \mathrm{~g} /$ day in the rate of gain of lambs. It has been found that the contribution of clover to leaf growth (Laidlaw and Steen, 1989) and to intake (Milne, Hodgson, Thompson, Souter and Barthram, 1982) can be considerably greater than its presence in herbage mass would suggest. Thus, it is possible that in the present experiment improved performance of lambs on grass/clover swards was the result of much higher proportions of clover in the diet than indicated by the proportion of 0.03 measured in cut herbage. It is also possible that the presence of clover may have stimulated a greater intake, or on the other hand, that intake and/or performance may have been reduced as a result of high levels of $\mathrm{N}$ used on grass swards.

Lambs appeared to be less sensitive to sward height in spring than in autumn. Over the range from 3 to $9 \mathrm{~cm}$, daily live-weight changes in lambs increased from +212 to $+305 \mathrm{~g}$ /day before weaning and from -18 to $+170 \mathrm{~g} /$ day in autumn. Thus, the ability of ewes to make use of body reserves during lactation may have limited the effect of reduced pasture availability at the lower grazing heights before weaning.

The relationship between sward height and rate of gain in ewes agreed with the relationship between sward 
height and intake suggested by Penning (1986), with little indication of improving performance beyond $6 \mathrm{~cm}$. However, there was evidence that with lambs, during the spring and particularly during the autumn period, rates of gain continued to increase up to $9 \mathrm{~cm}$ with no indication of maximum values within the range of heights examined. The results would suggest that for maximum lamb performance sward heights in excess of $7 \mathrm{~cm}$ may be required.

The low proportion of clover in grass/clover swards, while effective in stimulating animal performance, apparently resulted in poor stock-carrying capacity. Up to weaning grass/clover swards carried proportionately $0 \cdot 66$ of the stock carried on grass/nitrogen swards while during the autumn period the equivalent proportion was $0 \cdot 51$. However, because of the effect of clover on animal performance, lamb gain per ha on grass/clover swards was proportionately 0.72 of that on grass/nitrogen swards before weaning and 0.67 during the autumn period.

On grass/clover paddocks maintained at $9 \mathrm{~cm}$ height, clover content by the end of 1988 was significantly lower than that on other clover plots. While there was no evidence of a difference between other sward heights in this respect, results seem to indicate that clover may be under more competition with longer grass.

These results emphasize the significance of sward height in determining animal performance and stock-carrying capacity throughout the season. There was little evidence of a difference in the reaction of grass/clover and grass/nitrogen swards to sward height. However, productivity of grass/clover swards was much lower than that of grass/nitrogen swards, probably due to the low clover content under the continuous grazing system adopted.

\section{REFERENCES}

GibB, M. J. and Treacher, T. T. 1984. The performance of weaned lambs offered diets containing different proportions of fresh perennial ryegrass and white clover. Animal Production 39: 413-420.

HodGSON, J. 1986. Grazing behaviour and herbage intake. In Grazing (ed. J. Frame), Occasional Symposium, British Grassland Society, No. 19, pp. 51-64.

Laidlaw, A. S. and Steen, R. W. J. 1989. Turnover of grass lamina and white clover leaves in mixed swards continuously grazed with steers at a highand low-N fertilizer level. Grass and Forage Science 44: 249-258.

MARsh, R. and Laidlaw, A. S. 1978. Herbage growth, white clover content and lamb production on grazed ryegrass/white clover swards. Journal of the British Grassland Society 44: 249-258.

Maxwell, T. J. and Treacher, T. T. 1987. Decision rules for grassland management. In Efficient Sheep Production from Grass (ed. J. E. Pollott), Occasional Symposium, British Grassland Society, No. 21, pp. 67-78.

Milne, J. A., Hodgson, J., Thompson, R., Souter, W. G. and Barthram, G. T. 1982. The diet ingested by sheep grazing swards differing in white clover and perennial ryegrass content. Grass and Forage Science 37: 209-218.

Newton, J. E., Wilde, R. M. and Betts, J. E. 1984. The effect of sward and grazing management on lamb production. In Forage Legumes (ed. J. D. Thompson), Occasional Symposium, British Grassland Society, No. 16, pp. 109-111.

Penning, P. D. 1986. Some effects of sward condition on grazing behaviour and intake by sheep. In Grazing Research at Northern Latitudes (ed. O. Judmundsson), pp. 219-226. Plenum Publishing Corporation. 